\title{
Adventitious rooting of auxin-treated Lavandula dentata cuttings
}

\author{
Enraizamento adventício de estacas de Lavandula dentata tratadas com auxina
}

\author{
Claudine Maria de Bona ${ }^{I}$ Luiz Antonio Biasi ${ }^{I I}$ Bernardo Lipski ${ }^{I I}$ \\ Magda Aparecida Maia Masetto ${ }^{\text {IV }}$ Cícero Deschamps ${ }^{\text {II }}$
}

\begin{abstract}
Lavandula species may be propagated by seeds. However, plants will present expressive variation both in size and essential oil content. Indole-3-butyric acid (IBA) is a growth regulator which efficiently stimulates rooting and the objective of this research was to observe the influence of different IBA concentrations on rooting of $\boldsymbol{L}$. dentata cuttings. Herbaceous cuttings with approximately $10 \mathrm{~cm}$ in length and around $1 / 3$ of leaf retention had their bases submerged into 0 (control), 500, $1.000,2.000$ or $3.000 \mathrm{mg} \mathrm{dm}^{-3}$ of IBA diluted in de-ionized water for 30 seconds and placed in polystyrene foam trays filled with commercial substrate and kept under intermittent mist system. Averages of root number, length of the longest root, fresh and dry root weight, and percentage of rooted cuttings were evaluated after 60 days. There was no significant difference between treatments for the length of root, fresh and dry root weight. The percentage of rooted cuttings increased with IBA concentrations. A quadratic regression was obtained to root number. The $2.000 \mathrm{mg} \mathrm{dm} \mathrm{m}^{-3}$ dose increased the percentage of rooted cuttings and the mean root number per cutting. $\mathbf{L}$. dentata cuttings are easy to root.
\end{abstract}

Key words: IBA, vegetative propagation, French lavender.

\section{RESUMO}

Espécies de Lavandula podem ser propagadas por sementes. Entretanto, as plantas apresentarão elevada variabilidade em tamanho e em produção de óleo essencial. $O$ ácido indol-3-butírico (AIB) é um regulador de crescimento que eficientemente estimula o enraizamento. O objetivo deste trabalho foi observar a influência de diferentes concentrações de AIB no enraizamento de estacas de L. dentata. Estacas herbáceas com aproximadamente $10 \mathrm{~cm}$ de comprimento e $1 /$ 3 de retenção foliar tiveram suas bases submersas em 0 (controle), 500, 1.000, 2.000 ou $3.000 \mathrm{mg} \mathrm{dm}^{-3}$ de AIB diluído em água deionizada por 30 segundos e colocadas em bandejas de isopor contendo substrato comercial sob sistema de nebulização intermitente. As médias de número de raízes, comprimento da raiz mais longa, massa fresca e seca de raízes e porcentagem de estacas enraizadas foram avaliadas após 60 dias. Não houve diferença significativa entre os tratamentos para o comprimento da raiz e a massa fresca e seca de raízes. A porcentagem de estacas enraizadas aumentou com a concentração de AIB. Uma regressão quadrática foi obtida para o número de raízes. A concentração de $2.000 \mathrm{mg} \mathrm{dm}^{-3}$ aumentou a porcentagem de estacas enraizadas e o número de raízes formadas por estaca. As estacas de L. dentata são de fácil enraizamento.

Palavras-chave: AIB, propagação vegetativa, alfazema.

Lavandula dentata (French lavender) (Lamiaceae family) is a native Mediterranean small shrub with lignified stem base, whose leaves are green and finely dentated with terminal spike bluish flowers blooming almost continuously. Considered an aromatic plant, it is present in essences, fragrances and perfumes worldwide and it is also used in the popular medicine (GEMTCHÚJNICOV, 1976).

Accordingly to some authors, Lavandula species may be propagated by cuttings. However,

\footnotetext{
IInstituto Agronômico do Paraná (IAPAR), Pólo Regional de Curitiba, Centro Administrativo do Governo do Estado. Rua Máximo João Kopp, 274, Bloco 1, Ala Sul, 82630-900, Curitiba, PR, Brasil. E-mail: debona@iapar.br. Autor para correspondência. IDepartamento de Fitotecnia e Fitossanitarismo, Setor de Ciências Agrárias, Universidade Federal do Paraná (UFPR), Curitiba, PR, Brasil. IIICurso de Agronomia, UFPR, Curitiba, PR, Brasil.

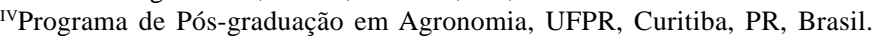


rooting capacity is poor. Conversely, if propagated by seeds, plants will present expressive variation both in size and essential oil content (DIAS et al., 2002; CHISHTI et al., 2006; TYUB et al., 2007). IBA is a growth regulator which efficiently stimulates rooting and presents advantageous characteristics over other auxins such as lower mobility and light degradation and higher chemical stability in the plant (HARTMANN et al., 2002).

The objective of this research was to observe the influence of different IBA concentrations on rooting of $\boldsymbol{L}$. dentata cuttings in order to promote vegetative propagation of this species.

The experiment was conducted in a greenhouse pertaining to the Plant Science Department, at the Agrarian Sciences Section of the Federal University of Parana, in Curitiba, Parana, Brazil. Lavandula dentata herbaceous cuttings with approximately $10 \mathrm{~cm}$ in length and around $1 / 3$ of leaf retention (apical part) were collected from stock plants located at the Canguiri Experimental Station of the Federal University of Parana, and had their bases submerged for 30 seconds into 0 (control), 500, 1.000, 2.000 or $3.000 \mathrm{mg} \mathrm{dm}^{-3}$ indole-3-butyric acid (IBA) deionized aqueous solutions (powdered IBA was diluted in $50 \%$ ethanol) and placed in Plantmax ${ }^{\circledR}$ filled polystyrene foam trays, which were kept under intermittent mist system. A voucher specimen was deposited in the herbarium of the UFPR's Department of Botany (excicata no. UPCB 61.305). A completely randomized experimental design with eight cuttings per different IBA treatment and four replications was applied. After two months, averages of root number, length of the longest root, fresh and dry root weight, and percentage of rooted cuttings were evaluated.

Root length (10,3, 10,5, 10,4, 8,5, 7,6cm) was inversely and root fresh (1,36, 1,80, 1,82, 2,35, 2,46g) and dry $(117,124,114,157,159 \mathrm{mg})$ weights were directly proportional to IBA concentration (0, 500, 1.000, 2.000, $3.000 \mathrm{mg} \mathrm{dm}^{-3}$ ). Such results were not statistically significant but may indicate a tendency of root quality improvement with the higher IBA doses tested, since heavier roots are considered desirable, while longer roots are not, because they tend to break during planting, exposing tissue to infections, and have to be pruned.

The percentage of rooted cuttings increased with IBA concentration (Figure 1) and it was high, over $96 \%$, with concentrations of 2.000 and $3.000 \mathrm{mg} \mathrm{dm}^{-3}$ IBA, showing that $L$. dentata cuttings are easy to root. IBA greatly increased number of roots and improved quality of roots which were better distributed as they emerged from diverse nodes on the cutting and not only from the cutting cut base. They were shorter and more resistant, different from the fewer control roots, which were long and turgid and broke easily at touch. A root number quadratic regression line could be obtained (Figure 2). The $2.100 \mathrm{mg} \mathrm{dm}^{-3}$ IBA was the

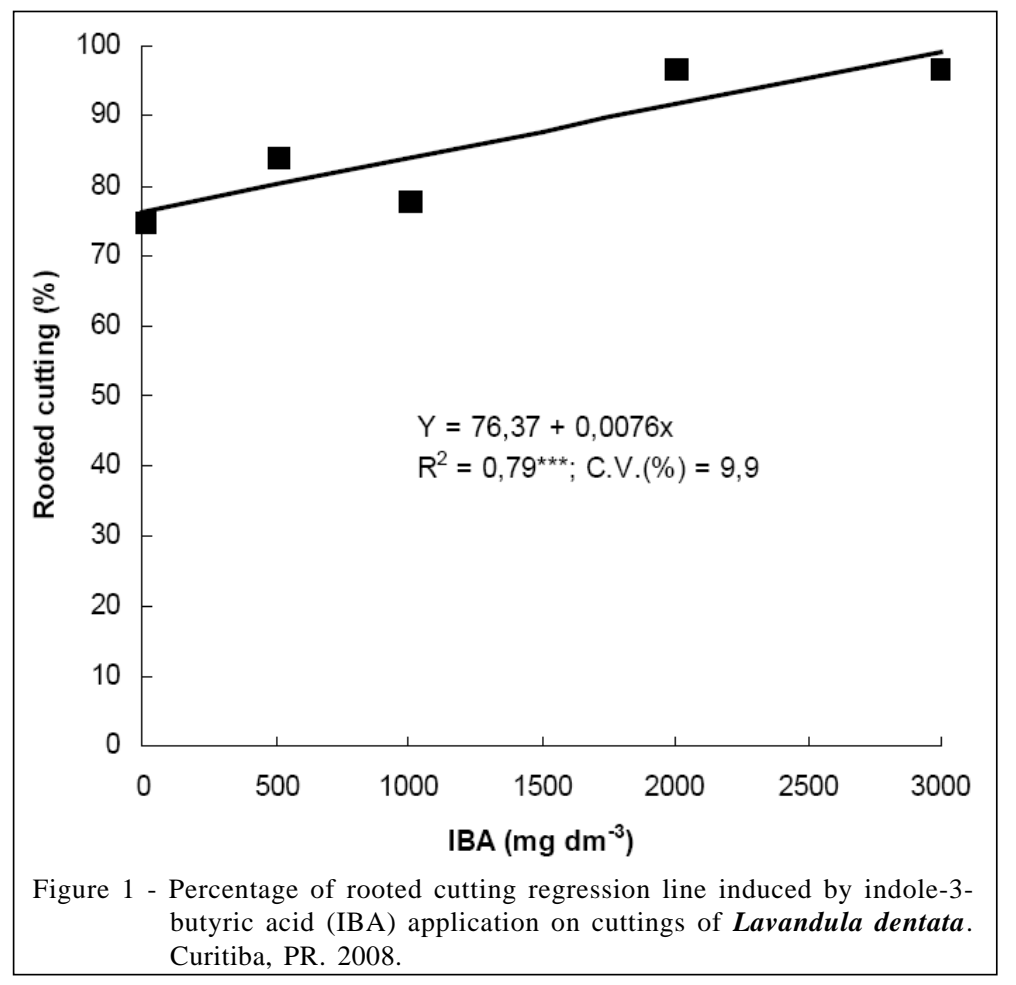

Ciência Rural, v.40, n.5, mai, 2010. 


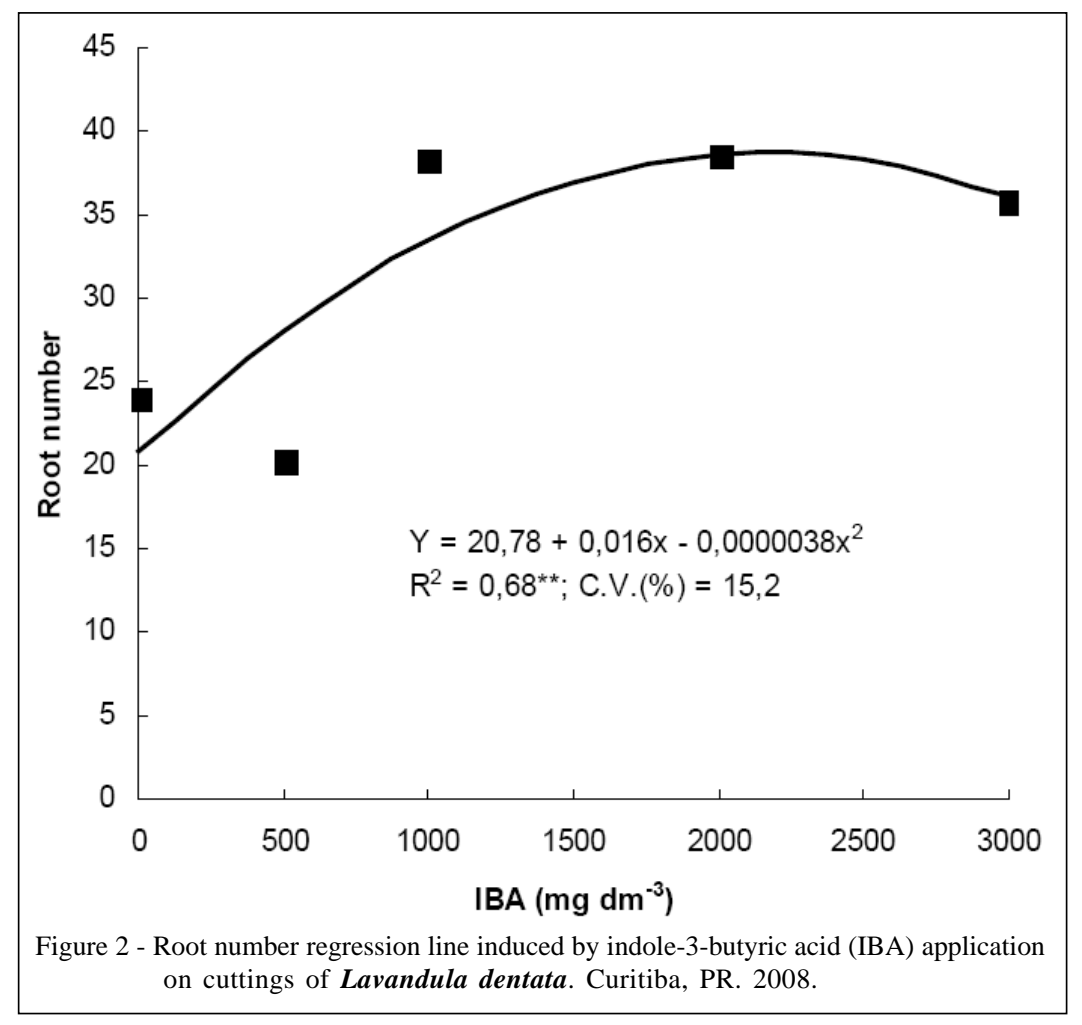

dose estimated by the regression equation which more induced formation of roots. Root formation slightly started to decrease with $3000 \mathrm{mg} \mathrm{dm}^{-3}$, which may indicate IBA toxicity. Such increment in root number; the better distribution of roots around the cutting stem; the better quality of the roots, which were fibrous to the touch and more resistant to handling; are all desirable characteristics since they allow roots to hold better to the substrate and to improve transplanting (HARTMANN et al., 2002).

Similarly to results presented herein, CHAGAS et al. (2008) observed that $2.000 \mathrm{mg} \mathrm{dm}^{-3}$ of IBA promoted the highest rooting and calli percentages and the greatest average number of roots on peach and Japanese apricot cuttings. In BORTOLINI et al. (2008), IBA was efficient for rooting induction of Tibouchina sellowiana cuttings, independently if used liquid or in powder, being concentrations among 1.500 and $3.000 \mathrm{mg} \mathrm{dm}^{-3}$ the best ones; and GARCÍA et al. (2005) obtained rooting percentages higher than $80 \%$ on cuttings of Gmelina arborea, a species with great domestication potential; and toxicity with higher IBA doses was also observed on cutting propagation of Acca sellowiana, a South American native species, by FRANZON et al. (2004).

Contrarily to the beneficial auxin effects reported herein and above, for cutting propagation of
Baccharis trimera, an herbaceous medicinal plant, IBA was considered not necessary, as similar rooting was obtained with or without it. The effect of naphthalene acetic acid (NAA), another auxin, however, was considered damaging to the cuttings (BONA et al., 2005). Different concentrations of NAA were also tested on medicinal Mikania micrantha cuttings by FERRIANI et al. (2007) and considered unnecessary. Hence, the necessity of external auxin application will depend on diverse factors and must be adjusted to species and conditions applied.

The conclusions were: the $2.000 \mathrm{mg} \mathrm{dm}^{-3}$ dose increased the percentage of rooted cuttings and the mean root number per cutting; $\boldsymbol{L}$. dentata cuttings are easy to root.

\section{ACKNOWLEDGEMENTS}

To CNPq for a Post-Doc scholarship to the first author and a Productivity Research Grant to the second author.

\section{REFERENCES}

BONA, C.M. et al. Estaquia de três espécies de Baccharis. Ciência Rural, v. 35, n. 1, p. 223-226, 2005. Available from: $<$ http://www.scielo.br/scielo.php?script=sci_pdf\&pid=S0103$84782005000100037 \& \operatorname{lng}=p t \& n r m=i s o \& t l n g=p t>$. Accessed: set. 06, 2009. doi: 10.1590/S0103-84782005000100034. 
BORTOLINI, M.F. et al. Tibouchina sellowiana (Cham.) Cogn.: enraizamento, anatomia e análises bioquímicas nas quatro estações do ano. Ciência Florestal, v. 18, n. 2, p. 159-171, 2008.

CHAGAS, E.A. et al. Enraizamento de estacas lenhosas de pessegueiro e clones de umezeiros submetidos à aplicação de AIB. Ciência e Agrotecnologia, v.32, n.3, p.986-991, 2008. Available from: <http:/ /www.scielo.br/scielo.php?script=sci_arttext \&pid=S141370542008000300043\&lng=pt\&nrm=iso>. Accessed: set. 06, 2009. doi: $10.1590 /$ S1413-70542008000300043.

CHISHTI, N. et al. Rapid in vitro clonal propagation of Lavandula officinalis chaix: a multipurpose plant of industrial importance. Pakistan Journal of Biological Sciences, v. 9, p. 514-518, 2006

DIAS, M.C. et al. Rapid clonal multiplication of Lavandula viridis L'H'er through in vitro axillary shoot proliferation. Plant Cell, Tissue and Organ Culture, v.68, p.99-102, 2002. Available from: <http://www.springerlink.com/content/ v501247321h16227/?p=c7fa01ea13f9441c9411827e5d1 d0338\&pi=11>. Accessed: set. 06, 2009. doi: 10.1023/ A:1012963021126.
FERRIANI, A.P. et al. Influência da época do ano e das diferentes formas de aplicação de ácido naftaleno acético (ANA) no enraizamento de Mikania micrantha Kunth. Revista Brasileira de Plantas Medicinais, v.9, n.2, p.102-107, 2007.

FRANZON, R. et al. Efeito do AIB e de diferentes tipos de estaca na propagação vegetativa da goiabeira-serrana (Acca sellowiana Berg). Revista Brasileira de Agrociência, v.10, n.4, p.515-518, 2004.

GARCÍA, R. et al. Efecto del ácido indolbutírico (AIB) y tipo de estaca en el enraizado de Gmelina arborea Roxb. Revista Fitotecnia Mexicana, v.28, p.319-326, 2005.

GEMTCHÚJNICOV, I.D. Manual de taxonomia vegetal: plantas de interesse econômico - agrícolas, ornamentais e medicinais. São Paulo: Editora Agronômica Ceres, 1976. 368p.

HARTMANN, H.T. et al. Plant propagation: principles and practices. 7.ed. New Jersey: Prentice Hall, 2002. , 880p.

TYUB, S. et al. Effect of BAP on shoot regeneration in shoot tip cultures of Lavandula officinalis. Journal of Research \& Development, v.7, p.125-130, 2007. 